Doi: HTTPS://DOI.ORG/10.23910/IJEP/2019.6.2.0311

\title{
Fungicides for the Management of Grey Leaf Blight (Pestalotia Anacardii) of Mango
}

\author{
V. A. Patil ${ }^{1}$, B. P. Mehta ${ }^{2}$, A. J. Deshmukh ${ }^{3}$ and V. G. Bavalgave ${ }^{4}$ \\ ${ }^{1}$ Dept. of Plant Pathology, Soil and Water Management Research Unit, Navsari Agricultural University, Navsari, \\ Gujarat (396 450), India \\ ${ }^{2}$ Dept. of Plant Pathology, Aspee College of Horticulture and Forestry, Navsari Agricultural University, Navsari, \\ Gujarat (396 450), India \\ ${ }^{3}$ Dept. of Plant Pathology, College of Agriculture, Navsari Agricultural University, Waghai, Gujarat, India \\ ${ }^{4}$ Dept. of Agronomy, N.M. College of Agriculture, Navsari Agricultural University, Navsari, Gujarat (396 450), India
}

\section{Corresponding Author}

V. A. Patil

e-mail: vijay.patilagri@gmail.com

\author{
Article History \\ Article ID: IJEP0311 \\ Received in 08 $8^{\text {th }}$ May, 2019 \\ Received in revised form $18^{\text {th }}$ May, 2019 \\ Accepted in final form 26 $26^{\text {th }}$ May, 2019
}

\begin{abstract}
In the present study, seven fungicides and their combinations were evaluated against the grey leaf blight disease of mango. Minimum disease

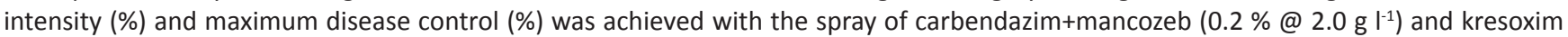
methyl (0.1\% @ $\left.1.0 \mathrm{ml} \mathrm{l}^{-1}\right)$ against grey leaf blight disease of mango. Carbendazim 12\%+mancozeb 63\% was found significantly superior over rest of the treatments with minimum grey leaf blight intensity ( $8.07 \%$ ) followed by kresoxim methyl 43\% SC (10.67\%). Copper oxychloride $50 \%$ WP was found to be the next best treatment in order of effectiveness which was at par with cymoxanil $8 \%+$ mancozeb $64 \%$ (12.74 \%).
\end{abstract}

Keywords: Fungicides, mango, Pestalotia anacardii

\section{Introduction}

Mango (Mangifera indica L.), an important fruit crop belongs to family Anacardiaceae and is believed to be originated within a large area including north-western Myanmar, Bangladesh and north-eastern India. Mango is also the national fruit of India, which is the largest producer of mango in the world accounting for $52-63 \%$ of total production. The genus, Mangifera comprises of 41 species (Mukherjee, 1985), however total reported species now stands at 39 (Mukherjee and Stolon, 1989). All the edible cultivars of mango represent the species indica which originated in the Indian sub-continent. Looking to the seriousness of the disease and economic importance of the crop in this area, present investigations were undertaken to study the efficacy of fungicides against disease and to generate necessary information for suitable chemical management measures to minimize crop losses.

\section{Materials and Methods}

A field experiment was conducted for two years to know the effect of different fungicides under in vivo condition. A susceptible cv. Kesar was used for the study at Agricultural Experimental Station Paria NAU, Navsari. Treatments with seven fungicides i.e. three systemic, two non systemic and two combination fungicides (Table 1) with one check were laid out in Randomized Block Design (RBD). Each treatment was replicated thrice. Three sprays were undertaken. First spray was given at the initiation of the disease followed by second and third spray at a monthly interval in the same orchard of cv. Kesar having 8 years old tree severely affected by grey leaf blight disease. The disease intensity (\%) was calculated at one day before each spray and 7 and 15 days after first, second and third spray. The data were analyzed as per randomized block design for interpretation and the disease control (\%) was also worked out.

Formula for calculating disease intensity (\%):

PDI $=(\Sigma$ Ratings of infected leaves observed $/$ No. of leaves observed $x$ Maximum disease score $) \times 100$

Observations with regards to symptoms were recorded on the basis of graded scale (0-5) (Patel, 1988):

\begin{tabular}{ll}
\hline Scale & Description \\
\hline 0 & Completely healthy - No spots \\
1 & 1 to $10 \%$ area of leaf infected \\
2 & 11 to $25 \%$ area of leaf infected \\
3 & 26 to $50 \%$ area of leaf infected \\
4 & 51 to $75 \%$ area of leaf infected \\
5 & More than $75 \%$ area of leaf infected and defoliation \\
\hline
\end{tabular}




\begin{tabular}{lll}
\hline $\begin{array}{l}\text { Table } \\
\text { concentration used }\end{array}$ \\
\begin{tabular}{lll}
\hline Tr. no. & Treatment Details & Quantity \\
\hline $\mathrm{T}_{1}$ & Carbendazim 50\% WP & $0.5 \mathrm{gl}^{-1}$ \\
$\mathrm{~T}_{2}$ & Thiophanate methyl 70\% WP & $1.0 \mathrm{~g} \mathrm{l}^{-1}$ \\
$\mathrm{~T}_{3}$ & Kresoxim methyl 43\% SC & $1.0 \mathrm{ml} \mathrm{l}^{-1}$ \\
$\mathrm{~T}_{4}$ & Copper oxychloride 50\% WP & $2.0 \mathrm{~g} \mathrm{l}^{-1}$ \\
$\mathrm{~T}_{5}$ & Copper hydroxide 77\% WP & $2.5 \mathrm{gl}^{-1}$ \\
$\mathrm{~T}_{6}$ & Carbendazim 12\%WP+mancozeb 63\%WP & $2.0 \mathrm{gl}^{-1}$ \\
$\mathrm{~T}_{7}$ & Cymoxanil 8\%+mancozeb 64\% WP & $2.0 \mathrm{gl}^{-1}$ \\
$\mathrm{~T}_{8}$ & Control & - \\
\hline
\end{tabular}
\end{tabular}

\section{Results and Discussion}

From the perusal of data presented in Table 2, it is clear that all the treatments significantly reduced the grey leaf blight intensity as compared to control. During the first year, carbendazim $12 \%+$ mancozeb $63 \%$ was found significantly superior over rest of the treatments with minimum grey leaf blight intensity (7.23\%) followed by kresoxim methyl $43 \%$ SC (10.12\%) which was at par with cymoxanil $8 \%+$ mancozeb $64 \%(11.24 \%)$. The next best treatment with lowest disease intensity was copper oxychloride 50\% WP (12.21\%) followed by carbendazim $50 \%$ WP (16.21\%) which was at par with thiophanate methyl 70\% WP (17.14\%) and was followed by copper hydroxide 77\% WP (21.12\%). In case of control, highest disease intensity (51.23\%) was recorded.

Maximum disease control (85.89\%) was observed in carbendazim $12 \%+$ mancozeb $63 \%$ which was followed in decreasing order by kresoxim methyl 43\% SC (80.25\%), cymoxanil 8\%+mancozeb $64 \%$ (78.06\%), copper oxychloride
$50 \%$ WP (76.17\%), carbendazim 50\% WP (68.36\%) and thiophanate methyl 70\% WP (66.54\%) whereas, copper hydroxide $77 \%$ WP had minimum disease control (58.77\%) during the first year of study.

In the second year, carbendazim $12 \%+$ mancozeb $63 \%$ was found significantly superior over rest of the treatments with minimum grey leaf blight intensity (8.91\%) followed by kresoxim methyl $43 \%$ SC $(11.21 \%)$ which was at par with copper oxychloride 50\% WP (12.23\%). The next best treatment in recording lowest disease intensity was cymoxanil $8 \%+$ mancozeb 64\% (14.23\%) and carbendazim 50\% WP (14.23 $\%)$ followed by thiophanate methyl 70\% WP (16.23\%) and copper hydroxide 77\% WP (17.84\%). In case of control, highest disease intensity (41.23\%) was recorded.

During second year of study, maximum disease control (78.39\%) was observed in carbendazim $12 \%+$ mancozeb $63 \%$, which was followed in decreasing order by kresoxim methyl $43 \%$ SC $(72.81 \%)$, copper oxychloride $50 \%$ WP (70.33\%), cymoxanil 8\%+mancozeb 64\%, carbendazim 50\% WP (65.48\%) and thiophanate methyl $70 \%$ WP (60.63\%) whereas, minimum disease control $(56.73 \%)$ was recorded in copper hydroxide $77 \%$ WP.

The pooled data for both the years indicated that among all the treatments, carbendazim $12 \%+$ mancozeb $63 \%$ was found significantly superior over rest of the treatments with minimum grey leaf blight intensity $(8.07 \%)$ followed by kresoxim methyl 43\% SC (10.67\%). The treatment copper oxychloride 50\% WP (12.22\%) was found to be the next best treatment in order of effectiveness which was at par with cymoxanil $8 \%+$ mancozeb $64 \%$ (12.74\%). The treatment carbendazim 50\% WP (15.22\%) was found to be superior over the treatment thiophanate methyl 70\% WP (16.69\%). The next best treatment in order of merit was copper hydroxide $77 \%$

Table 2: Efficacy of fungicides against grey leaf blight disease of mango cv. Kesar

\begin{tabular}{|c|c|c|c|c|c|c|c|}
\hline \multirow[t]{2}{*}{ Tr. No. } & \multirow[t]{2}{*}{ Dose } & \multicolumn{2}{|c|}{ I-Year } & \multicolumn{2}{|c|}{ II -Year } & \multicolumn{2}{|c|}{ Pooled } \\
\hline & & $\begin{array}{c}\text { Disease } \\
\text { intensity (\%) }\end{array}$ & $\begin{array}{c}\text { Disease } \\
\text { control (\%) }\end{array}$ & $\begin{array}{c}\text { Disease } \\
\text { intensity (\%) }\end{array}$ & $\begin{array}{l}\text { Disease } \\
\text { control (\%) }\end{array}$ & $\begin{array}{c}\text { Disease } \\
\text { intensity (\%) }\end{array}$ & $\begin{array}{c}\text { Disease } \\
\text { control (\%) }\end{array}$ \\
\hline $\mathrm{T}_{1}$ & $0.5 \mathrm{~g} \mathrm{l}^{-1}$ & $23.71^{*}(16.21)^{* *}$ & 68.36 & $22.12^{*}(14.23)^{* *}$ & 65.48 & $22.92^{*}(15.22)^{* *}$ & 67.08 \\
\hline$T_{2}$ & $1.0 \mathrm{~g} \mathrm{l}^{-1}$ & $24.44(17.14)$ & 66.54 & $23.74(16.23)$ & 60.63 & 24.10 (16.69) & 63.91 \\
\hline$T_{3}$ & $1.0 \mathrm{mll}^{-1}$ & $18.52(10.12)$ & 80.25 & $19.53(11.21)$ & 72.81 & $19.00(10.67)$ & 76.93 \\
\hline $\mathrm{T}_{4}$ & $2.0 \mathrm{~g} \mathrm{l}^{-1}$ & $20.43(12.21)$ & 76.17 & $20.45(12.23)$ & 70.33 & $20.45(12.22)$ & 73.57 \\
\hline $\mathrm{T}_{5}$ & $2.5 \mathrm{~g} \mathrm{l}^{-1}$ & $27.35(21.12)$ & 58.77 & $24.97(17.84)$ & 56.73 & $26.18(19.48)$ & 57.86 \\
\hline $\mathrm{T}_{6}$ & $2.0 \mathrm{~g} \mathrm{I}^{-1}$ & $15.58(7.23)$ & 85.89 & $17.35(8.91)$ & 78.39 & $16.49(8.07)$ & 82.54 \\
\hline $\mathrm{T}_{7}$ & $2.0 \mathrm{~g} \mathrm{I}^{-1}$ & $19.57(11.24)$ & 78.06 & $22.12(14.23)$ & 65.48 & $20.87(12.74)$ & 72.45 \\
\hline $\mathrm{T}_{8}$ & - & $45.69(51.23)$ & 0.00 & $39.93(41.23)$ & 0.00 & $42.82(46.23)$ & 0.00 \\
\hline \multicolumn{2}{|c|}{ SEm \pm} & 0.48 & & 0.36 & & 0.34 & \\
\hline \multicolumn{2}{|c|}{$C D(p=0.05)$} & 1.46 & & 1.10 & & 1.04 & \\
\hline \multicolumn{2}{|l|}{ C.V. \% } & 7.38 & & 6.61 & & 6.44 & \\
\hline
\end{tabular}

*: Figures indicate arc sin transformed values; ${ }^{* *}$ : Figures in parenthesis are original values 
WP (19.48\%). In control, highest disease intensity (46.23\%) was recorded.

Maximum disease control (82.54\%) was observed in carbendazim $12 \%+$ mancozeb $63 \%$ which was followed in decreasing order by kresoxim methyl 43\% SC (76.93\%), copper oxychloride 50\% WP (73.57\%), cymoxanil 8\%+mancozeb 64\% (72.45\%), carbendazim 50\% WP (67.08\%) and thiophanate methyl 70\% WP (63.91\%) whereas, copper hydroxide $77 \%$ WP had minimum disease control of $57.86 \%$.

Similar results were reported previously for bioefficacy of fungicides under field condition by Chauhan (1984) who reported that carbendazim $(0.3 \%)$ at pea stage before maturation of stone reduced the incidence of grey leaf blight disease of mango. Later on, Karthikeyan et al. (2002) reported that thiophanate methyl and carbendazim at $2.0 \%$ application in coconut were found best in reduction of the grey leaf blight disease index to 18.6 and $20.9 \%$, respectively after three years of application. Kyada (2006) observed that among systemic, non-systemic and combination of fungicides, carbendazim+mancozeb $(0.1 \%)$ was the best to reduce grey leaf blight disease with $69.30 \%$ reduction followed by carbendazim $(0.05 \%)$ and iprodine+carbendazim $(0.025 \%)$ tested in vivo. These results are in confirmation with earlier workers. Das and Mahanta (1985), as well as Patel (1988) reported Bavistin effective against the growth of $P$. palmarum and $P$. mangiferae, respectively. Khalequzamman et al. (2003) observed that among six fungicides, Bavistin 50\% WP (carbendazim) 0.1\% found better in controlling leaf spot of sapota caused by Pestalotia sapotae. Bavistin 50\% WP (carbendazim), copper oxychloride and carbendazim $12 \%+$ mancozeb $63 \%$ were completely inhibitory to Pestalotiopsis sp. (Pandey et al., 2006; Rokade, 2009).

\section{Conclusion}

Among all the fungicides tested in vivo against grey leaf blight of mango, carbendazim 12\%+mancozeb 63\% (0.2\% @ $2.0 \mathrm{~g}$ $\left.\mathrm{I}^{-1}\right)$ was found significantly superior with minimum grey leaf blight intensity followed by kresoxim methyl 43\% SC (0.1\% @ $\left.1.0 \mathrm{ml} \mathrm{l}^{-1}\right)$. Copper oxychloride 50\%WP $\left(0.2 \% @ 2.0 \mathrm{~g}^{-1}\right)$ was found to be the next best treatment in order of effectiveness which was at par with cymoxanil $8 \%+$ mancozeb $64 \%(0.2 \%$ @ $2.0 \mathrm{~g} \mathrm{l}^{-1}$ ).

\section{Acknowledgement}

The authors express their gratitude to The Director of research, Dean P.G. Studies, Navsari Agricultural University, Navsari, Gujarat for providing necessary facilities during the present investigations. Authors are also thankful to ITCC. IARI, New Delhi for identification of the pathogen.

\section{References}

Chauhan, H.L., 1984. Phytopathological causes of mango decline in South Gujarat and their possible control measures. Ph.D. Thesis, G.A.U., Dantiwada, 17-75.

Das, C.M., Mahanta, I.C., 1985. Evaluation of some fungicides against Pestalotia palmarum $\mathrm{Cke}$., incitant of grey blight of coconut. Pesticides 16, 37-38.

Karthikeyan, M., Sarala, L., Karunanithi, K., Rajarethinam, S., 2002. Control of leaf blight disease of coconut in Tamil Nadu. Indian Coconut 32, 6-7.

Khalequzamman, K.M., Md Khalim Uddin, Hossain, M.S., Islam, M.S., Rashid, M.H., 2003. Yearly incidence and effect of fungicides in controlling leaf spot of sapota. Asian Journal of Plant Science 2, 442-444.

Kyada, J.Z., 2006. Investigation on grey blight (Pestalotiopsis guepinii (desm.) stey.) of mango (Mangifera indica L.). M.Sc. Thesis submitted to J.A.U., Junagadh, 19-64.

Mukherjee, S.K., 1985. Distribution of species on the mango genepool, IBPGR, FAO, Rome, 112.

Mukherjee, S.K., Stolon, Van D.H., 1989. Mango germplasm- a global perspective 231, 75-82.

Pandey, A., Shukla, A.N., Chandra, S., 2006. Pestalotiopsis Stem canker of Jatropha curcas. Indian Forester 132, 763-766.

Patel, R.B., 1988. Studies on grey leaf spot of mango [Pestalotiopsis mangiferae (Henn.) Steyaert] and its control. M.Sc. Thesis, G.A.U., Navsari, 12-71.

Rokade, R.A., 2009. Investigation on grey leaf spot/blight of coconut (Cocos nucifera Linn.) caused by Pestalotia palmarum (Cooke) Steyaert under South Gujarat. M.Sc. Thesis, N.A.U., Navsari, 28-70. 